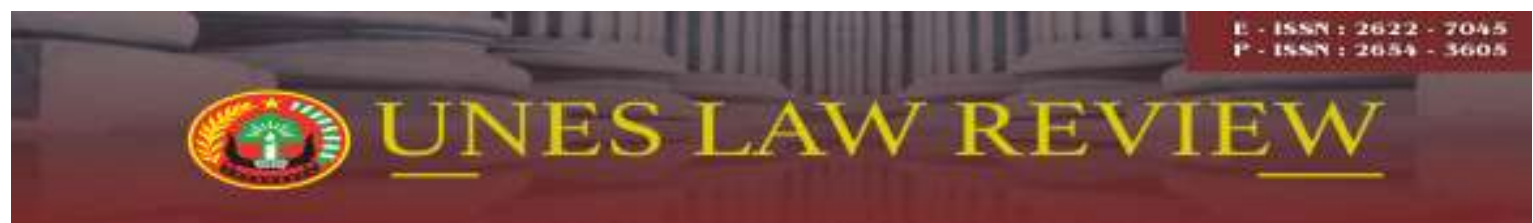

Email: uneslawreview@gmail.com

Online: http://review-unes.com/index.php/law

Volume 2, Issue 2, Desember 2019

\title{
ANALISIS PENYELESAIAN SENGKETA HARTA BERSAMA AKIBAT PUTUSAN PERKAWAINAN KARENA KEMATIAN
}

\author{
Devirianti Effendi \\ Dosen Fakultas Hukum, Universitas Ekasakti, Padang, Indonesia \\ E-mail : deviriantieffendi69@gmail.com
}

\begin{abstract}
ABSTRAK
Sebagai sarana perlindungan, dijadikan sebagai kedok untuk memperoleh keuntungan atau demi kepentingan sepihak dan memandang tidak lagi sebagai subjek yang harus dilindungi kepentingannya menjadi sebuah objek diam yang lemah. Untuk itulah diperlukan penanganan yang serius agar masalah ini tidak dijadikan kesempatan bagi pihak-pihak yang mencari keuntungan sendiri, maka dalam hal pembagian harta bersama akibat kematian sangat menarik untuk dikaji. Dari latar belakang diatas maka penulis tertarik mengangkat masalah penyelesaian sengketa harta bersama akibat putusnya perkawinan karena kematian. Adapun ruang lingkup atau rumusan masalah yang dimaksud adalah sebagai berikut, Pertama, Bagaimana penyelesaian sengketa harta bersama akibat putusnya perkawinan karena kematian, Kedua, Upaya penyelesaian sengketa harta bersama akibat putusnya perkawinan karena kematian. Dari rumusan masalah ini maka metode penulisan ini adalah Yaitu dengan jalan membaca bahan-bahan tulisan ilmiah, buku-buku literatur, Peraturan-peraturan Perundang-undangan dan berbagai konsep lainnya yang dipandang dapat menambah kejelasan permasalahan dan arah pembahasan yang ada relevan dalam Penulisan. Dan Comperastive Study yaitu dengan cara membaca dan membandingbandingkan berbagai teori yang ada untuk mendapatkan kesimpulan yang dapat dijadikan bahan dalam penyusunan ini. Dalam penulisan ini teknik analisa data yang digunakan adalah analisa data secara kuantitatif, yaitu memberikan pembahasan atau suatu penjelasan tentang bahan Penulisan yang datanya mengarah pada kajian yang bersifat teoritis mengenai konsep-konsep dan berbagai bahan hukum lainnya, yaitu dimana pernyataan khusus dikaitkan dengan pernyataan umum yang diperoleh dilapangan. Jadi janganlah kita mengucilkan janda. Janda juga ingin didengar dan diayomi bukan menjadi bahan pergunjingan, apalagi jika janda itu, menyembuhkan psikis sangatlah berat bagi seorang janda. Mencoba menutup telinga demi dan menguatkan dari gunjingan orang lain. Janda itu tidak selamanya jelek, tidak selamanya mengganggu hubungan orang, tidak selamanya dia hina. Janda bisa berkarya, bisa menciptakan lapangan pekerjaan dan bisa menjaga perilakunya. Jadi terima kami, hargai kami karena kami juga bisa menjadi orang yang bermanfaat dan membanggakan untuk kalian.
\end{abstract}

Kata Kunci: Penyelesaian Sengketa, Harta Bersama, Perkawainan 


\section{PENDAHULUAN}

Permaslahan muncul dalam keluarga adalah harta warisan yang ditinggalkan oleh yang telah meninggal dunia, bukan saja pada anak-anak atau istri tapi juga bias antara mertua dan menantu, maka Inti dari permasalahan ini adalah ada pada manusia, suatu kehidupan manusia tidaklah kompleks bilamana orang tersebut tidak memiliki rasa hormat dan apalagi tidak peduli dengan orang disekitarnya hanya karena harta benda, sehingga menampakan sifat-sifat manusia itu. Akan tetapi kadangkala naluri itu terbentuk pada takdir Ilahi dimana kehendak seseorang.

Kehidupan manusia umumnya tidak pernah puas dengan apa yang dirasakan dan dialaminya, sehingga berbagai usaha yang dilakukan untuk dapat memenuhi kepuasan. Demikian juga kedudukan anak tersebut dalam masyarakat masih dipengaruhi oleh perlakuan dan pertimbangan hukum tertentu.

Dengan memperhatikan berbagai pertimbangan tersebut, maka didalam hal pengangkatan anak yang dilakukan menurut adat dan kebiasaan yang harus dilaksanakan dengan mengutamakan kepentingan kesejahteraan. Dengan menyimak penjelasan, Jika tidak sesuai dengan ketentuan-ketentuan dan peraturan-peraturan yang relevan antara fenomena yang ada dan saling mempengaruhi, tentu dalam hal ini akan menimbulkan dampak yang negatif terhadap pelaksanaan berbagai aspek kesejahteraan maupun dari aspek kedudukan serta kepastian hukumnya.

Dalam hukum Indonesia kita, mengenal ada beberapa macam istilah yang berhubungan dengan pengangkatan anak, masing-masing tertuju pada bentuk sebagaimana yang diatur dalam Burgelijk Weatboek (BW) sebagaimana yang diketahui pula, dengan menyimak dan menelaah berbagai uraian tersebut diatas dengan demikian ada tiga stelsel atau sistem hukum yaitu sistem hukum barat (BW), sistem hukum adat dan sistem hukum islam. Pada ketiga sistem hukum atau stelse hukum tersebut itulah yang akan penulis tempati dan soroti tentang status dan kedudukan yang dimaksud.

Dalam Kitab Undang-undang Hukum Perdata (KUH Perdata) kita tidak menemukan suatu aturan atau ketentuan yang mengatur tentang masalah yang dihadapi, yang ada hanyalah ketentuan tentang landasan diterimanya undang-undang tersebut adalah bahwa setelah perang. Dalam hukum adat sesungguhnya. Dengan demikian tentunya akan terdapat beberapa perbedaan di masing-masing daerah hukum adat di Indonesia tentang 
masalah yang bersumber dari ketentuan-ketentuan yang terdapat dalam burgelijk weatboek (BW) dan hukum adat yang berlaku di masyarakat Indonesia maupun hukum islam yang merupakan konsekuensi logis dari masyarakat Indonesia yang mayoritas mutlak beragama islam.

Ketiga sistem hukum yang dikemukakan diatas, belum terlihat adanya suatu persamaan yang memberikan suatu kepastian hukum masalah pengangkatan anak sebagai bentuk pelaksanaan kesejahteraan anak yang bertujuan memberikan suatu perlindungan secara optimal. Optimalisasi adanya kepastian hukum tujuannya adalah menghindarkan terjadi penyelewengan yang dapat menghilangkan tujuan awal dari subjek yang seharusnya dilindungi hak-hak yang sesuai dengan asas.

Sebagai sarana perlindungan, dijadikan sebagai kedok untuk memperoleh keuntungan atau demi kepentingan sepihak dan memandang tidak lagi sebagai subjek yang harus dilindungi kepentingannya menjadi sebuah objek diam yang lemah. Untuk itulah diperlukan penanganan yang serius agar masalah ini tidak dijadikan kesempatan bagi pihak-pihak yang mencari keuntungan sendiri, maka dalam hal pembagian harta bersama akibat kematian sangat menarik untuk dikaji.

Dari latar belakang diatas maka penulis tertarik mengangkat masalah penyelesaian sengketa harta bersama akibat putusnya perkawinan karena kematian. Adapun ruang lingkup atau rumusan masalah yang dimaksud adalah sebagai berikut:

1. Bagaimana penyelesaian sengketa harta bersama akibat putusnya perkawinan karena kematian?

2. Upaya penyelesaian sengketa harta bersama akibat putusnya perkawinan karena kematian?

\section{METODE PENELITIAN}

Metode penelitian yang telah digunakan adalah penelitian hukum empiris. Penelitian hukum empiris adalah penelitian hukum sosiologis yang dapat disbeut juga dengan penelitian lapangan.

Teknik analisa data yang digunakan adalah analisa data secara kuantitatif, yaitu memberikan pembahasan atau suatu penjelasan tentang bahan Penulisan yang datanya mengarah pada kajian yang bersifat teoritis mengenai konsep-konsep dan berbagai bahan 
hukum lainnya, yaitu dimana pernyataan khusus dikaitkan dengan pernyataan umum yang diperoleh dilapangan. Hasil Penulisan dari data yang diperoleh baik secara tertulis maupun secara lisan dari perilaku nyata yang diamati itu dipelajari serta dibahas yang utuh untuk diungkapkan dalam pembahasan ini.

\section{PEMBAHASAN DAN HASIL PENELITIAN}

\section{Penyelesaian Sengketa Harta Bersama antara Menentau dan Mertua}

Pembahasan ini lebih awal penulis jabarkan sebagaimana Prinsip Pewarisan Menurut KUHPerdata dan Hukum Islam, prinsip pewarisan menurut KUHPerdata adalah hubungan darah. Yang berhak mewaris adalah yang punya hubungan darah, kecuali suami/isteri pewaris. (Pasal 832 KUHPerdata).

Sementara, yang berhak mewaris menurut hukum Islam berdasarkan Pasal 171 huruf c Kompilasi Hukum Islam, yaitu mereka yang:

1. Mempunyai hubungan darah dengan pewaris,

2. Mempunyai hubungan perkawinan (dengan pewaris),

3. Beragama Islam,

4. Tidak dilarang Undang-Undang selaku ahli waris

Dengan demikian, dalam hal mertua janda tersebut (ayah/ibu kandung suami) meninggal dunia, maka yang berhak menggantikan kedudukan almarhum suami janda tersebut hanyalah keturunan langsung dari almarhum suami janda tersebut, yaitu anaknya. Dalam hukum waris Perdata Barat (nasional) hal ini sebagaimana diatur dalam Pasal 842 KUHPerdata yang berbunyi:

"Penggantian dalam garis lurus ke bawah yang sah, berlangsung terus dengan tiada akhirnya...."

Jadi, cucu dari pewaris menggantikan kedudukan anak pewaris (suami si janda). Dengan demikian, hak/bagian dari cucu adalah sebesar bagian dari anak pewaris yang digantikan (karena telah meninggal terlebih dahulu dari pewaris). Hal ini sesuai dengan Pasal 841 KUHPerdata yang berbunyi:

"Pergantian memberi hak kepada seorang yang mengganti,untuk bertindak sebagai pengganti dalam derajat dan dalam segala hak orang yang diganti"

Untuk bagian dari anak kandung suami janda dimaksud (cucu pewaris) adalah bergantung pada jumlah ahli waris lain dari Pewaris. Karena posisi cucu menggantikan 
anak pewaris, maka bagian dari cucu adalah sama dengan bagian dari anak pewaris. Misalnya:

Bagian anak adalah 1/3 bagian dari seluruh harta peninggalan, maka bagian cucu (anak kandung dari suami janda tersebut) sebagai ahli waris pengganti (bijplaatsvervulling) adalah $1 / 3$ bagian juga. Jika cucu yang menggantikan ada lebih dari 1 orang (misalnya 3 orang), maka bagiannya adalah $1 / 3 \times 1 / 3$ bagian $=$ $1 / 6$ bagian.

Satu hal yang perlu diperhatikan, jika suami janda tersebut meninggal sebelum mertuanya meninggal dunia (pewaris), maka sang suami sempat menjadi ahli waris dari ayahnya. Dalam hal kemudian suami juga meninggal dunia (setelah pewaris), maka janda bisa mendapat bagian warisan, tetapi sebagai ahli waris dari almarhum suaminya.

Sebagai penutup, jika suami janda tersebut tidak memiliki keturunan (anak kandung atau anak luar kawin yang telah diakui sah sebelum dia meninggal dunia), maka bagian dari suami (dari mertua janda tersebut) digantikan oleh anak yang lain, atau ke keluarga mertua atau orang tua dari mertua sebagai ahli waris golongan II. Kata cerai menurut Kamus Besar Bahasa Indonesia berarti pisah atau putus hubungan sebagai suami istri.

Berdasarkan Pasal 38 UU No. 1 Tahun 1974 tentang Perkawinan (“UUP”), perkawinan menjadi putus karena kematian, perceraian, dan atas keputusan pengadilan. Namun, dalam UUP tidak disebutkan secara khusus definisi dari cerai hidup dan cerai mati.

Frasa cerai hidup dan cerai mati dapat kita temui dalam Inpres No. 1 Tahun 1991 tentang Penyebarluasan Kompilasi Hukum Islam (“KHI”) yakni dalam beberapa pasal berikut:

Pasal 8

Putusnya perkawinan selain cerai mati hanya dapat dibuktikan dengan surat cerai berupa putusan Pengadilan Agama baik yang berbentuk putusan perceraian, ikrar talak, khuluk, atau putusan taklik talak.

Pasal 96

(1) Apabila terjadi cerai mati, maka separoh harta bersama menjadi hak pasangan yang hidup lebih lama.

(2) Pembagian harta bersama bagi seorang suami atau istri yang istri atau suaminya hilang harus ditangguhnya sampai adanya kepastian matinya yang hakiki atau matinya secara hukum atas dasar putusan Pengadilan Agama. 
Pasal 97

Janda atau duda cerai hidup masing-masing berhak seperdua dari harta bersama sepanjang tidak ditentukan lain dalam perjanjian perkawinan.

Walaupun dalam KHI menyebut adanya frasa cerai hidup dan cerai mati, tetapi tidak ditemukan pula definisi cerai hidup dan cerai mati. Definisi cerai mati dan cerai hidup ternyata dapat ditemui pada definisi yang diberikan oleh Badan Pusat Statistik pada bagianistilah statistik:

Cerai Mati:

Cerai mati adalah status dari mereka yang ditinggal mati oleh suami/isterinya dan belum kawin lagi.

Cerai Hidup:

Cerai hidup adalah status dari mereka yang hidup berpisah sebagai suami isteri karena bercerai dan belum kawin lagi. Dalam hal ini termasuk mereka yang mengaku cerai walaupun belum resmi secara hukum. Sebaliknya, tidak termasuk mereka yang hanya hidup terpisah tetapi masih berstatus kawin, misalnya suami/isteri ditinggalkan oleh isteri/suami ke tempat lain karena sekolah, bekerja, mencari pekerjaan, atau untuk keperluan lain. Wanita yang mengaku belum pernah kawin tetapi pernah hamil, dianggap cerai hidup.

Berdasarkan definisi di atas, cerai mati dapat diartikan sebagai putusnya perkawinan karena salah satu pihak (suami atau istri) meninggal dunia sehingga meninggalkan pasangannya. Sedangkan cerai hidup dapat diartikan sebagai putusnya perkawinan dalam keadaan suami istri masih hidup karena suatu alasan. Mengenai alasanalasan yang dapat dijadikan dasar perceraian bisa dilihat dalam Penjelasan Pasal 39 ayat (2) UUP jo Pasal 116 KHI.

\section{Upaya Penyelesaian Sengketa Harta Bersama Akibat Putusnya Perkawinan Karena Kematian}

Jadi, dasar hukum dari cerai mati dan cerai hidup sebenarnya diatur dalam UUP maupun KHI, yaitu mengenai putusnya perkawinan. Namun, memang tidak diberikan secara khusus definisi cerai mati dan cerai hidup dalam peraturan perundang-undangan yang ada. Janda berarti wanita yang tidak bersuami lagi, baik karena cerai maupun karena ditinggal mati oleh suaminya. 
Pria maupun wanita yang telah menikah kemudian berpisah, baik disebabkan karena perceraian maupun kematian adalah berstatus sama. Yang disayangkan, budaya ketimuran memberi kesan negatif kepada janda daripada duda. Kaum janda seringkali ditempatkan sebagai wanita pada posisi yang rendah, lemah, tidak berdaya dan membutuhkan belas kasih sehingga dalam kondisi sosial budaya seringkali terdapat ketidakadilan.

Semakin maju zaman dan pendidikan tidak membuat stigma status janda membaik. Lihat saja beberapa lagu, film dan beberapa oknum yang menjelekkan/merendahkan status janda itu sendiri. Seorang janda sering diperlihatkan sebagai wanita lemah, tak berdaya, bahkan menjadi si penggoda suami orang. Saat seorang wanita berstatus janda, maka selentingan negatif mulai bertebaran. Berbeda dengan pria yang terlihat tetap terhormat dengan status sebagai duda. Di budaya kita sendiri, seorang janda akan menjadi pergunjingan luar biasa. Apalagi di daerah pedesaan, dimana kata janda masih awam sekali di telinga mereka. Menjadi janda itu sangat rentan dari segala permasalahan dan pandangan masyarakat sehingga banyak dari mereka yang sedikit berlebihan dalam menanggapi status itu.

Yang sering dikesampingkan masyarakat, seorang janda justru sering menanggung beban lebih berat dibanding duda. Di satu sisi dia berperan sebagai ibu dari anak-anak yang (seringkali) ditelantarkan oleh ayahnya, di sisi lain dia harus berperan sebagai kepala keluarga untuk memberi nafkah pada anak-anaknya. Tentu saja berat menjadi seorang janda, dia harus tetap menjaga harkat dan martabat dirinya di tengah-tengah stigma negatif masyarakat dan harus mampu bertahan demi diri sendiri dan anak-anak tanpa didampingi sesosok pria yang bisa menjaga, menyayangi dan mengayominya. Menjadi seorang janda bukanlah sebuah cita-cita, keinginan, maupun harapan seorang wanita. Tidak ada seorangpun di dunia ini yang menginginkan menyandang status janda, bahkan status janda merupakan status sangat ditakutkan oleh seluruh wanita di dunia ini.

Menurut Ollenburger dan Moore mengenai norma yang berlaku di masyarakat, menyatakan bahwa kehidupan seorang wanita yang menyandang status janda sangat memengaruhi psikis dikarenakan wanita cenderung hidup lebih lama dari pria. Wanita pada umumnya menikahi pria yang usianya lebih tua dari mereka sendiri, pria tua lebih mungkin menikah kembali dibandingkan wanita tua. Adanya norma-norma sosial yang 
kuat, yang menentang perempuan tua yang menikahi pria muda, dan juga norma-norma yang menentang wanita tua menikah lagi.

Menjadi janda sesungguhnya adalah hal yang serba salah, bagaimana tidak janda akan diliputi kegalauan luar biasa tentang statusnya sekarang. Akankah status itu dia buka ke masyarakat luas atau hanya dia simpan untuk dirinya sendiri. Walaupun sebenarnya semua akan terbongkar jika akan tiba saatnya semua itu terbongkar. Hal inilah yang sering menyebabkan psikis seorang janda sendiri terganggu, janda takut mengungkapkan statusnya tetapi jika tidak diungkapkan akan lebih sakit slentingan yang beredar tentang status yang ia sandang saat ini.

Hal lain yang sering ditakutkan wanita dengan status janda adalah banyak laki-laki yang akan masuk dalam kehidupannya dan membanggakan tentang dirinya dan niat baiknya untuk menikahi seorang janda. Selain itu akan banyak juga pria mencoba mengelabui janda agar jatuh dalam pelukannya, sebab janda sering dianggap wanita lemah dan haus akan kasih sayang. Banyak kasus pria menggoda seorang janda dengan imingiming kebahagiaan sesaat.

Alasan itulah yang sering membuat para janda menutupi statusnya, sebab khawatir banyak laki-laki datang hanya untuk menganggu dan menggoda. Sedangkan ketika mereka tidak mengungkapkan status janda secara jujur, sulit bagi janda itu sendiri untuk mencari pengganti suami mereka lagi. Tidak ada seorang janda pun yang ingin untuk berlama-lama menyandang status janda, dan manusiawi sekali jika janda menginginkan dia diayomi, dilindungi dan disayang layaknya wanita pda umumnya.

\section{PENUTUP}

Akhir dari dilema seorang janda adalah menjadi diam dengan statusnya, diam menerima perilaku yang tidak menyenangkan dan menjadi seseorang yang tertutup. Berat menyembuhkan luka yang mereka rasakan, berdiri sendiri menyandang tugas ganda, menjadi kuat untuk anak-anaknya, menghilangkan rasa trauma yang ia rasakan dan anaknya (jika terjadi KDRT dalam keluarganya). 


\section{DAFTAR PUSTAKA}

\section{Buku:}

Amriani, Nurnaningsih. Mediasi Alternatif Penyelesaian Sengketa Perdata di Pengadilan. Jakarta: Raja Grafindo Persada.2012

Chomzah, Ali Achmad. Seri Hukum Pertanahan III Penyelesaian Sengketa Hak Atas Tanah dan Seri Hukum Pertanahan IV Pengadaan Tanah Instansi Pemerintah. Jakarta: Prestasi Pustaka.2003

Nader, Laura \& Todd Jr, Harry F. The Disputing Process Law in Ten Societies. New York: Columbia University Press, 1978,

Pruitt, Dean G \& Rubin, Z. Konflik Sosial. Yogyakarta: Pustaka Pelajar, 2004,

Rahmadi, Takdir. Mediasi Penyelesaian Sengketa Melalui Pendekatan Mufakat. Jakarta: Rajawali Pers.2011,

\section{Undang-Undang:}

Kitab Undang-Undang Hukum Perdata (Burgerlijk Wetboek, Staatsblad 1847 No. 23)

Undang-Undang Nomor 1 Tahun 1974 tentang Perkawinan, http://www.bps.go.id

Instruksi Presiden Nomor 1 Tahun 1991 tentang Penyebarluasan Kompilasi Hukum Islam.

\section{Website:}

Departemen Pendidikan Nasional, 2003, di uopdate pada tanggal 24052019

https://www.kajianpustaka.com/2018/10/pengertian-jenis-penyebab-dan-penyelesaiansengketa.html

https://www.hukumonline.com/klinik/detail/ulasan/lt509540729faa9/warisan

Jawaban pertanyaan tersebut ada pula penjelasannya di buku Kiat Cerdas Mudah dan Bijak Dalam Memahami HUKUM WARIS - karya: Irma Devita Purnamasari, SH, MKn (Kaifa, Desember 2012).

https://eprints.uny.ac.id/22029/4/4.BAB\%20II.pdf

https://www.fimela.com/lifestyle-relationship/read/3768556/stigma-negatif-janda-danbeban-berat-yang-tak-dipahami-masyarakat, di update pada tanggal 5 Juni 2019

https://medium.com/@indonesiagodigital1/menyelesaikan-pembagian-harta-gono-ginidengan-baik-dan-adil-53fab634888a 